\title{
THE BIBLIOMETRIC PROFILE OF ARTICLES WRITTEN BY FEMALE AUTHORS IN THE FIELD OF PUBLIC RELATIONS AT REFEREED JOURNALS OF COMMUNICATION FACULTIES IN TURKEY
}

\author{
Filiz BALTA PELTEKOĞLU ${ }^{\mathrm{a}}$, Emel TOZLU ${ }^{\mathrm{b}}$
}

\begin{abstract}
Bibliometrics is defined as the application of mathematical and statistical methods to books and other communication environments (Pritchard 1969: 348). In this context, the findings obtained by bibliometric researches of scientific publications contribute to the determination of the present situation of a field of science and it can also provide an insight about its progress. The aim of this research is to carry out a bibliographic analysis of public relations articles written by female authors in the journals published by Communication faculties in Turkey. In the research, in order to reveal the profile of the academic articles written by the female authors in the field of public relations in Turkey, the faculty journals compliant with the determined criteria in the field of communication were handled.In this context, the first 10 years of the first communication faculties, which were transformed from the School of Press and Broadcasting to Communication Faculties in 1992, and in which the Public Relations Departments were established in 1993 were included in the study with their academic journals in ULAKBIM, which were accessible online. It was observed that 4 journals were suitable according to the mentioned criteria and the research was carried out in this scope. In this context, all the articles since the initial publication dates of the four faculty magazines were scanned and 275 articles in the field of Public Relations were identified out of 2.586 articles. Of these articles, 140 were identified as single female author articles and coded by two authors and subjected to bibliometric analysis. The questions asked in this study are: QS1: What is the gender distribution of authors of academic publications in the field of public relations? Q2: What is the qualitative-theoretical / quantitative ratio of scientific publications made by female authors in the field of public relations? Q3: What is the distribution of all public relations articles published by the female authors since the first issue of journals which are covered in this research? Q4: What is the distribution of scientific publications made by female authors in the field of public relations according to years? Q5: What is the distribution of scientific publications made by female authors in the field of public relations according to the provinces represented by authors? Q6: What is the distribution of scientific publications made by female authors in the field of public relations according to the institutions represented by the authors? Q7: What is the distribution of scientific publications made by female authors in the field of public relations according to their subjects? It was not possible to make a comparison between the findings of the researches due to the fact of interruption of publications for some years, differences in years etc. It is foreseen, however, that the research will provide an analysis of the existing academic work published by female authors in the field of public relations in Turkey.
\end{abstract}

Key words: Public relations, bibliometrics, communication, women

\footnotetext{
a Marmara University, Faculty of Communication. filiz@marmara.edu.tr

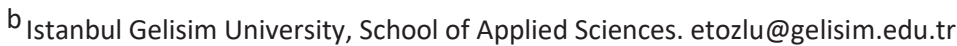




\section{INTRODUCTION}

The concept of bibliometrics was first used by Alan Pritchard in his article "Statistical Bibliogaphy or Bibliometrics?" which was published in he Journal of Documentation (1969), and since then the concept was used and improved in various fields. Pritchard defines the concept as "a mathematical and statistical method that can be used for books or other communication media" (Pritchard, 1969, pp. 368-349). Today, bibliometric analyzes are frequently encountered in scientific publication such as thesis, article, book, etc. written in academic context. In this context, the data gathered bibliometrically for the purposes of scientific studies may vary. When we consider the studies conducted in general; we can say that data is gathered according to criteria such as citation, institution, subject, gender and distribution in years.

Koehler (2001: 120) notes that people engaged in bibliometrics can be separated into four groups;

* Those who study on citation analysis,

* Those who focus on co-citation analyis,

* Those who are interested in the productivity of people, institutions or countries,

* Those who conduct studies in relation with information products such as book, article, patent etc.

In this context, he states that data is gathered according to criteria such as citation, institution, subject, gender and distribution in years (Koehler, 2001). Today, bibliometric analyzes are frequently encountered in scientific publication such as thesis, article, book, etc. written in academic context. It can be said that the scientific studies conducted by this method of analysis can show variability in the data they gather bibliometrically for their purposes. In Turkey, it is possible to reach publications containing bibliometrical analysis, which are based on journals and subject (cinema, tv, public relations, etc.). In Turkey there are academic articles dealing with doctorate and master theses on public relations and communication in various forms. There are some journal based (Okay, 2016 \& Saniye, U. L. U., \& AKDAĞ, M., 2015) and subject based ( cinema-TV etc.) bibliometric analysis on the different field of communication and public relations (Atabek\&Atabek,2009) as well. In this study we aim to investigate the numerical distribution of the articles written by female authors in the academic literature in the field of public relations by considering all the articles written by female authors, published since the first issue of academic journals, article and subject distributions, distribution of number of authors, numerical distribution of articles, year of publication, the universities and provinces of authors and thereby aiming to reveal the general profile of the articles written by female authors. In this context, it is foreseen that data for scientific findings may be obtained by some characteristics of documents as a result of research conducted in the field of public relations, and the findings may provide an insight about how public relations has progressed in terms of gender and to establish a road map.

\section{ACADEMIC BACKGROUND OF THE CONCEPT OF PUBLIC RELATIONS IN TURKEY}

Considering the history of public relations education on the world scale, we can say that the foundation was laid in the United States at the beginning of the twentieth century, long before Turkey. One of the first examples in this context is Edward L. Bernays' "Crystallizing Public Opinion", which is a scientific study on public relations. After Bernays published this work, he began to started to teach courses on this subject at New York University (Peltekoğlu 2016: 115). 
In Turkey, public relations education began in the middle of the 1960s at Ankara University Political Sciences Faculty School of Press and Broadcasting, which is followed by Istanbul University School of Journalism and Public Relations, Ankara Academy of Economic and Commercial Sciences School of Journalism and Public Relations, Istanbul Academy of Economic and Commercial Sciences School of Journalism and Public Relations, Ege University School of Journalism and Public Relations and Eskisehir Commercial Academy of Science's Faculty of Communication Sciences was followed in 1980. In 1982, first five institutions took the name of the School of Press and broadcasting which were transformed into Communication faculties by the law number 3837 issued in 1992. Thus, the number of communication faculties is 7 with Konya Selçuk University, where education in public relations departments has started.

After the significant transformation in 1992, new communication faculties were opened within other state universities. Faculty of Communication at Galatasaray University in Istanbul in 1994, Faculty of Communication at Ataturk University in Erzurum in 1997, Faculty of Communication at Firat University in Elazığ, Faculty of Communication at Kocaeli University in 1998 and Faculty of Communication at Akdeniz University in 1999 were established and as the number of communication faculties increased in state universities, undergraduate programs on communication were also established within fine art faculties (Tokgöz 2003: 7). Today there are more than 60 college of communication in Turkey both public and private. According to Peltekoğlu (2016: 158); those wish to receive training in the field of public relations should know the political systems and management theories and develop their skills in writing and speaking. Critical reading should be among the fundamental courses in public relations education, as it gives the ability to express ideas clearly and meaningfully in writing.
For this reason, good public relations education at the undergraduate level is possible through a training program consisting of communication and public relations courses built on basic courses of liberal arts education in one aspect, rather than a curriculum dedicated to a number of specialized fields. Taking all these reasons into consideration, causality can be brought into the transformation of communication faculties in Turkey. In this context, considering that the transformation in communication faculties in Turkey is as of 1992, scientific journals affiliated to communication faculties were also established, and therefore the articles which have been started to be published academically on communication - has gained momentum.

\section{CONCEPT OF PUBLIC RELATIONS AND WOMEN}

It can be argued that the place of women in the concept of public relations has a very important profile since Doris Bernays. Today in the United States $55 \%$ of people studying in the field of public relations are women. According to the reports of PRSSA (Public Relations Student Society of America) 1984-1985, the proportion of female members, which was $35 \%$ in 1970-1971, has reached to 79 $\%$. Although it is difficult to give exact figures about public relations in Turkey, 155 members among 259 TUHID members are women and this is a positive indicator (Peltekoğlu 2016: 150). The history of public relations as an academic discipline throughout its independence from public opinion, propaganda and advertisements is a relatively new process. Moreover, the history of Public Relations discipline is even shorter when considered in terms of female academics who were trained in this field. The first book with the concept of public relations in Turkey was published in the middle of 1960's and the first book written by female academicians who were trained in Public Relations as a graduate 
of the Faculty of Communication was published in 1992.

The book, titled "Introduction to Public Relations", was extended and re-published in 1998 under the title "What is Public Relations?" and it is the most printed academic book on public relations with its recent 9th Edition.

\section{PURPOSE OF THE STUDY}

The purpose of this research carried out by female academicians is to reveal the profile of women in the academic world which contributes to the public relations sector in which women are more in numbers, by carrying out a bibliographic analysis of the articles related to the public relations published by the female authors in the journals published by Communication Faculties in Turkey.

\section{SAMPLE AND METHOD OF STUDY}

In the research, in order to reveal the profile of academic articles written by female authors in the field of public relations in Turkey, the journals of faculties that provide education in the field of communication have been considered. The journals of 7 communication faculties, which were established with the same law as the first communication faculties, in 1992 by transforming the Schools of Press and Communication and where the departments of public relations were established in 1993 are selected as samples. However, in order to provide accessibility to the articles and to provide meaningful data, the criteria was set as the journals being accessible online for a minimum of 10 years and those cited at ULAKBIM. Faculties of Communication at Anadolu University, Ege University and Galatasaray University, established by the same law mentioned above were left outside the scope due to the limited availability of online access, having very long breaks between publications and the faculties having no public relation departments. Four well-known scientific journals published within faculty of communications have been identified in accordance with the criteria. These journals are Gazi Communication Theory and Research Journal, Journal of Istanbul Communication Faculty, Journal of Marmara Communication and Journal of Selçuk Communication. The research covers all the articles in the field of public relations between the start date of publications until the year 2016. During the research, 275 papers written in the field of Public Relations which were published in four communication faculty magazines were identified. Of these articles, 140 were identified as single female papers and coded by two authors and subjected to bibliometric analysis. Bibliometric analysis method was used as research method. The data were obtained by conducting an online archive search within the scope of the questionnaire created, while the issues with access problems were accessed via the editors of journals. In this context, 140 of 275 articles published in the field of public relations (36 in Gazi Communication Theory and Research Journal between 1984-2016, 91 in Istanbul Journal of Faculty between 19922016, 57 in Marmara Communication Journal between 1992-2016, and 91 in Selcuk Communication Journal) as articles with single female author and their bibliometric analysis was done. The obtained data were transferred to the "SPSS for Windows 21.0" statistical package program and evaluated through this program. Since the study aimed to obtain data on all of the articles written by the female authors in the field of public relations, the comparison between the journals covered by the research was inevitably avoided because the beginning years of publication differed. The questions asked in this study are: 
Q1: What is the gender distribution of authors of academic publications in the field of public relations? Q2: What is the qualitative-theoretical / quantitative ratio of scientific publications made by female authors in the field of public relations? Q3: What is the distribution of all public relations articles published by the female authors since the first issue of journals which are covered in this research? Q4: What is the distribution of scientific publications made by female authors in the field of public relations according to years? Q5: What is the distribution of scientific publications made by female authors in the field of public relations according to the provinces represented by authors? Q6: What is the distribution of scientific publications made by female authors in the field of public relations according to the institutions represented by the authors? Q7: What is the distribution of scientific publications made by female authors in the field of public relations according to their subjects? The analysis to be conducted in accordance with obtained data will be used to determine the academic publications by female authors in the field of public relations and the research aims to make future assumptions.

\section{RESEARCH DATA AND FINDINGS}

\begin{tabular}{|l|c|c|c|c|c|c|}
\hline $\begin{array}{c}\text { Gen } \\
\text { der }\end{array}$ & $\begin{array}{c}\text { Gazi } \\
\text { Communic } \\
\text { ation } \\
\text { Journal of } \\
\text { Theory and } \\
\text { Research }\end{array}$ & $\begin{array}{c}\text { Istanbul } \\
\text { University, } \\
\text { Communic } \\
\text { ation } \\
\text { Faculty } \\
\text { Journal }\end{array}$ & $\begin{array}{c}\text { Marmara } \\
\text { University, } \\
\text { Communic } \\
\text { ation } \\
\text { Faculty } \\
\text { Journal }\end{array}$ & $\begin{array}{c}\text { Selcuk } \\
\text { Commu } \\
\text { nication } \\
\text { Faculty }\end{array}$ & $\begin{array}{c}\text { Tot } \\
\text { al }\end{array}$ & $\%$ \\
\hline $\begin{array}{l}\text { Fem } \\
\text { ale }\end{array}$ & 22 & 64 & 49 & 58 & 193 & 59 \\
\hline Male & 17 & 39 & 18 & 61 & 135 & 41 \\
\hline Total & 39 & 103 & 67 & 119 & 328 & 100 \\
\hline
\end{tabular}

Table 1: The gender distribution of authors of academic publications in the field of public relations

When we look at data on Table 1, which answers the question "What is the gender distribution of authors of academic publications in the field of public relations?"; we see that among
328 authors; $59 \%$ (193) are female and $41 \%$ (135) are male.

Figure 1: Chart of gender distribution of authors of academic publications in the field of public relations

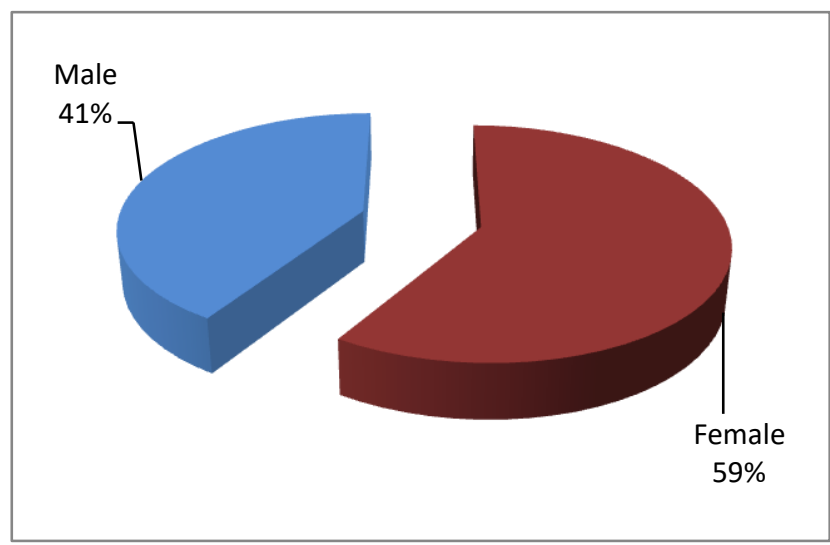

In general, when the gender distribution of authors of academic publications in the field of public relations is considered; it is seen that number of female authors which is 193 (59\%), is higher than the number of male authors which is 135 (41\%). 


\begin{tabular}{|l|c|c|c|c|c|}
\hline $\begin{array}{c}\text { Table of } \\
\text { articles } \\
\text { published by } \\
\text { single female } \\
\text { authors in the } \\
\text { field of public } \\
\text { relations in } \\
\text { accordance } \\
\text { with their type }\end{array}$ & $\begin{array}{c}\text { Gazi } \\
\text { Commun } \\
\text { ication } \\
\text { Journal } \\
\text { of } \\
\text { Theory } \\
\text { and } \\
\text { Research }\end{array}$ & $\begin{array}{c}\text { Istanbul } \\
\text { University } \\
\text { Communic } \\
\text { ation } \\
\text { Faculty } \\
\text { Journal }\end{array}$ & $\begin{array}{c}\text { Marmara } \\
\text { University } \\
\text { Communi } \\
\text { cation } \\
\text { Faculty } \\
\text { Journal }\end{array}$ & $\begin{array}{c}\text { Selcuk } \\
\text { Comm } \\
\text { unicat } \\
\text { ion } \\
\text { Facult } \\
\text { y }\end{array}$ & Total \\
\hline Quantitative & 6 & 8 & 1 & 6 & 21 \\
\hline $\begin{array}{l}\text { Qualitative/ } \\
\text { Theoretical }\end{array}$ & 15 & 44 & 34 & 26 & 119 \\
\hline Total & $\mathbf{2 1}$ & $\mathbf{5 2}$ & $\mathbf{3 5}$ & $\mathbf{3 2}$ & $\mathbf{1 4 0}$ \\
\hline
\end{tabular}

Table 2: Table of articles published by single female authors in the field of public relations in accordance with their type

When we look at data on Table 2, which answers the question "What is the qualitativetheoretical / quantitative ratio of scientific publications made by female authors in the field of public relations?"; we see that among 140 articles; 119 are Qualitative/ Theoretical and 21 of them are Quantitative articles.

\begin{tabular}{|c|c|c|c|}
\hline Journal Names & $\begin{array}{c}\text { Numbe } \\
\text { r of } \\
\text { articles } \\
\text { publish } \\
\text { ed by } \\
\text { single } \\
\text { female } \\
\text { author } \\
s \text { in the } \\
\text { field of } \\
\text { public } \\
\text { relatio } \\
\text { ns }\end{array}$ & $\begin{array}{c}\text { Total } \\
\text { numbe } \\
\text { r of } \\
\text { articles } \\
\text { publish } \\
\text { ed in } \\
\text { the } \\
\text { field of } \\
\text { public } \\
\text { relatio } \\
\text { ns }\end{array}$ & $\begin{array}{c}\text { Total } \\
\text { numbe } \\
\text { r of } \\
\text { articles } \\
\text { publish } \\
\text { ed in } \\
\text { the } \\
\text { journal }\end{array}$ \\
\hline & $\mathrm{N}$ & N & $\mathrm{N}$ \\
\hline $\begin{array}{l}\text { Gazi Communication Journal of Theory } \\
\text { and Research }\end{array}$ & 21 & 36 & 587 \\
\hline $\begin{array}{l}\text { Istanbul University, Communication } \\
\text { Faculty Journal }\end{array}$ & 52 & 91 & 990 \\
\hline $\begin{array}{l}\text { Marmara University, Communication } \\
\text { Faculty Journal }\end{array}$ & 35 & 57 & 449 \\
\hline Selcuk Communication Faculty & 32 & 91 & 560 \\
\hline Total & 140 & 275 & 2.586 \\
\hline
\end{tabular}

Table 3: The distribution of all public relations articles published since the first issue of journals which are covered in this research

When we look at data on Table 3, which answers the question; "What is the distribution of all public relations articles published by the female authors since the first issue of journals which are covered in this research?"; we see that the total number of articles in 4 journals is 2.586 . It has been determined that 275 articles are on public relations, and 140 of these articles (with single author) are written by female authors.

Figure 2: Chart of total number of articles written by single female authors in the field of public relations
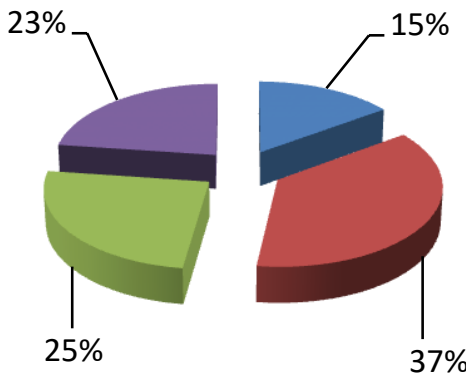

Gazi Communication Journal of Theory and Research

- Istanbul University, Communication Faculty Journal

Marmara University, Communication Faculty Journal

Selcuk Communication Faculty 


\begin{tabular}{|c|c|c|c|c|c|}
\hline $\begin{array}{c}\text { Table of } \\
\text { articles } \\
\text { publish } \\
\text { ed by } \\
\text { single } \\
\text { female } \\
\text { authors } \\
\text { in the } \\
\text { field of } \\
\text { public } \\
\text { relation } \\
\text { s in } \\
\text { accorda } \\
\text { nce } \\
\text { with } \\
\text { years }\end{array}$ & $\begin{array}{c}\text { Gazi } \\
\text { Communic } \\
\text { ation } \\
\text { Journal of } \\
\text { Theory and } \\
\text { Research }\end{array}$ & $\begin{array}{c}\text { Istanbul } \\
\text { University, } \\
\text { Communic } \\
\text { ation } \\
\text { Faculty } \\
\text { Journal }\end{array}$ & $\begin{array}{c}\text { Marmara } \\
\text { University, } \\
\text { Communic } \\
\text { ation } \\
\text { Faculty } \\
\text { Journal }\end{array}$ & $\begin{array}{l}\text { Selcuk } \\
\text { Communic } \\
\text { ation } \\
\text { Faculty }\end{array}$ & $\begin{array}{l}\text { Tot } \\
\text { al }\end{array}$ \\
\hline 1992 & 0 & 1 & 2 & 0 & 3 \\
\hline 1993 & 0 & 0 & 6 & 0 & 6 \\
\hline 1994 & 1 & 0 & 14 & 0 & $* 15$ \\
\hline 1995 & 0 & 0 & 3 & 0 & 3 \\
\hline 1996 & 0 & 4 & 0 & 0 & 4 \\
\hline 1997 & 2 & 2 & 0 & 0 & 4 \\
\hline 1998 & 0 & 5 & 0 & 0 & 5 \\
\hline 1999 & 2 & 3 & 1 & 0 & 6 \\
\hline 2000 & 2 & 3 & 0 & 4 & 9 \\
\hline 2001 & 1 & 0 & 3 & 1 & 5 \\
\hline 2002 & 2 & 9 & 0 & 2 & $\begin{array}{c}* 1 \\
3\end{array}$ \\
\hline 2003 & 1 & 3 & 0 & 2 & 6 \\
\hline 2004 & 0 & 4 & 0 & 1 & 5 \\
\hline 2005 & 2 & 7 & 0 & 2 & $\begin{array}{l}* * * \\
11\end{array}$ \\
\hline 2006 & 0 & 3 & 0 & 2 & 5 \\
\hline 2007 & 1 & 0 & 1 & 1 & 3 \\
\hline 2008 & 0 & 3 & 0 & 1 & 4 \\
\hline 2009 & 1 & 2 & 2 & 0 & 5 \\
\hline 2010 & 1 & 2 & 1 & 7 & $\begin{array}{l}* * * \\
11\end{array}$ \\
\hline 2011 & 0 & 0 & 0 & 2 & 2 \\
\hline 2012 & 0 & 0 & 1 & 0 & 1 \\
\hline 2013 & 1 & 1 & 0 & 1 & 3 \\
\hline 2014 & 2 & 0 & 0 & 1 & 3 \\
\hline 2015 & 2 & 0 & 0 & 4 & 6 \\
\hline 2016 & 0 & 0 & 1 & 1 & 2 \\
\hline Total & 21 & 52 & 35 & 32 & 140 \\
\hline
\end{tabular}

When we look at data on Table 4, which answers the question; "What is the distribution of scientific publications made by female authors in the field of public relations according to years?"; we see that there are 15 articles in 1994 (first), 13 articles in 2002 (second) and 11 articles in 2005 and 2011 (third).

Figure 3: Chart of total number of articles written by single female authors in the field of public relations according to years with highest rates

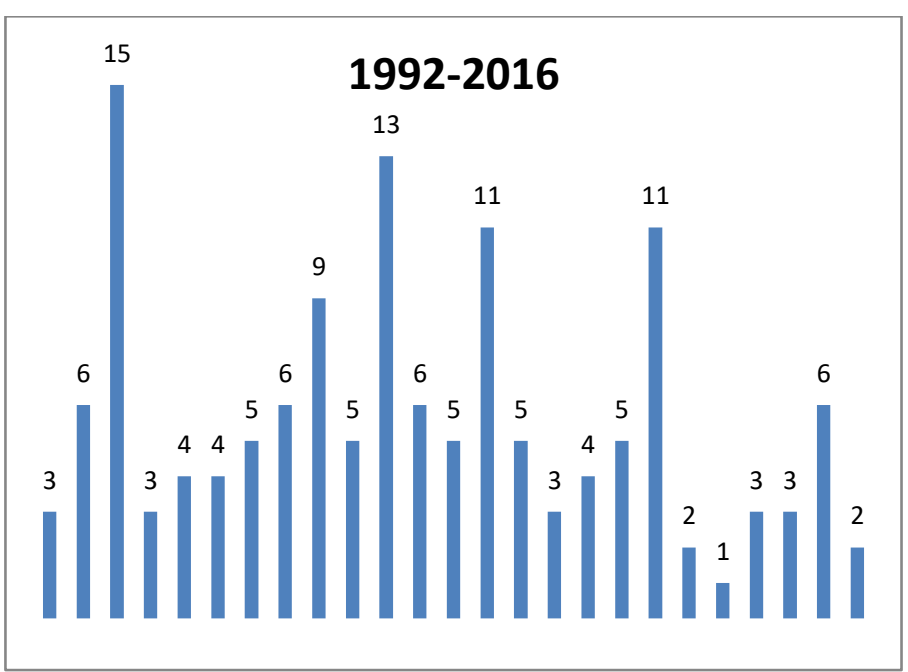

Table 4: Table of total number of articles written by single female authors in the field of public relations according to years 
Figure 4: Chart of total number of articles written by single female authors in the field of public relations according to years with highest rates

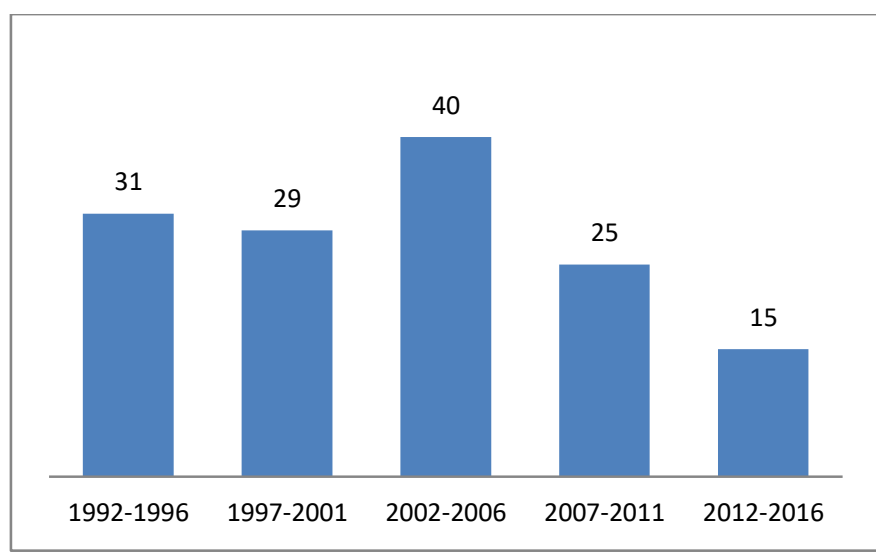

When the distribution charts of the single authored articles published in the field of public relations by the female authors are examined according to the distribution charts of five year periods, the highest number of publications (40) was made between 2002-2006; the second highest publication was published between 1992-1996 (31); and the number of publications between 2012-2016 is the lowest (15).

Figure 5: Chart of total number of articles written by single female authors in the field of public relations distributed according to the provinces they represent

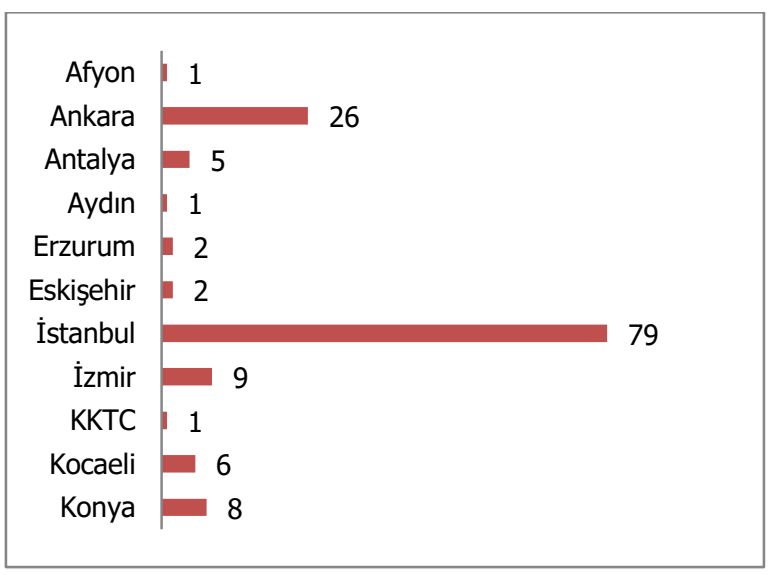

When we look at data on Figure 5, which answers the question; "What is the distribution of scientific publications made by female authors in the field of public relations according to the provinces where the institutions they are employed at/ they represent are located?"; we see that Istanbul is in first place with 79 authors writing articles in the field of public relations, followed by 26 authors from Ankara and 9 authors from Izmir.

Figure 6: : Chart of total number of articles written by single female authors in the field of public relations distributed according to the institutions they represent

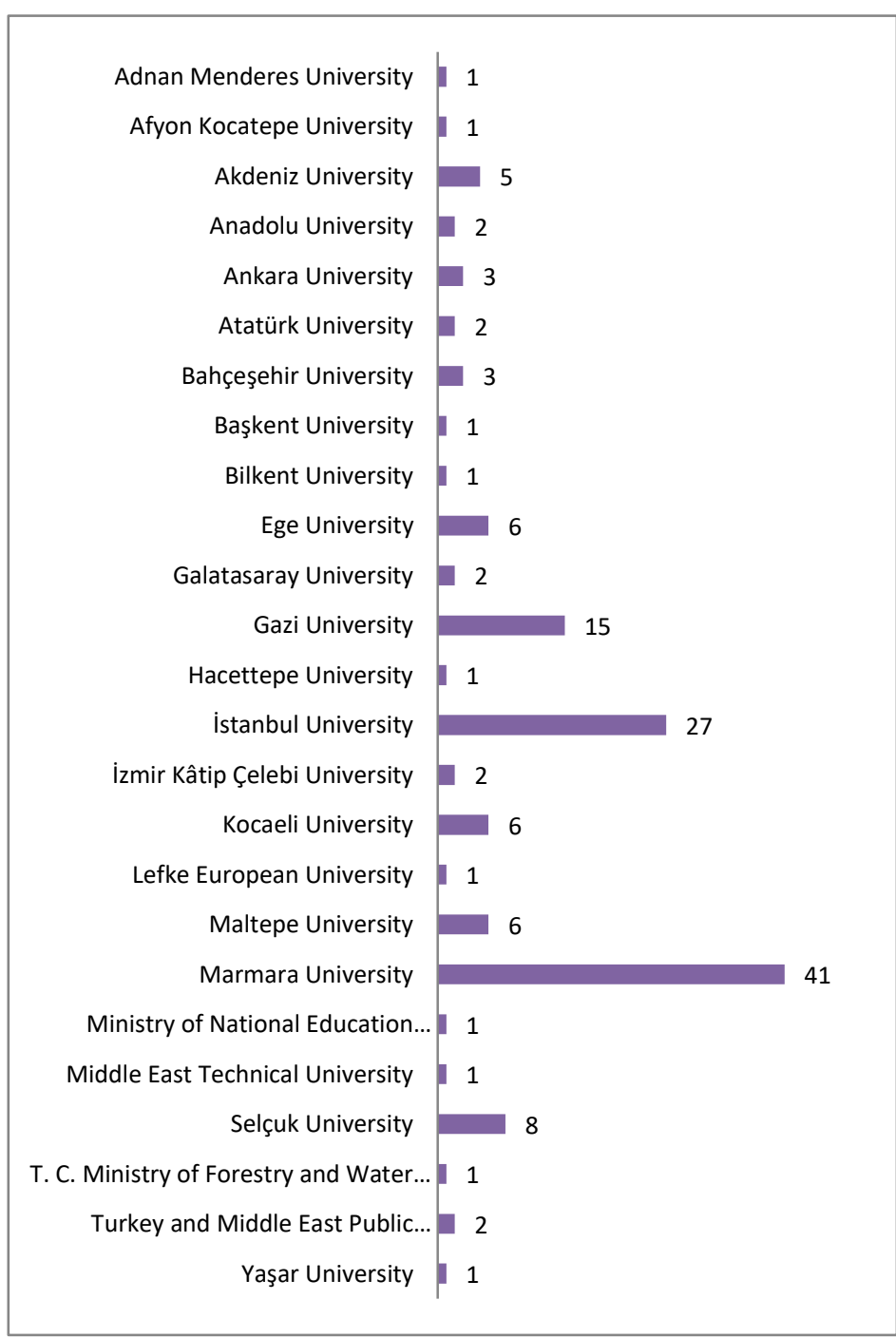

When we look at data on Figure 6 , which answers the question; "What is the distribution of scientific publications made by female authors in the field of public relations according to the 
institutions represented by the authors?"; we see that Marmara University is in first place with 41 authors writing articles in the field of public relations, followed by 21 authors from Istanbul University and 15 authors from Gazi University.

Figure 7: Chart of total number of articles written by single female authors in the field of public relations distributed according to their subject

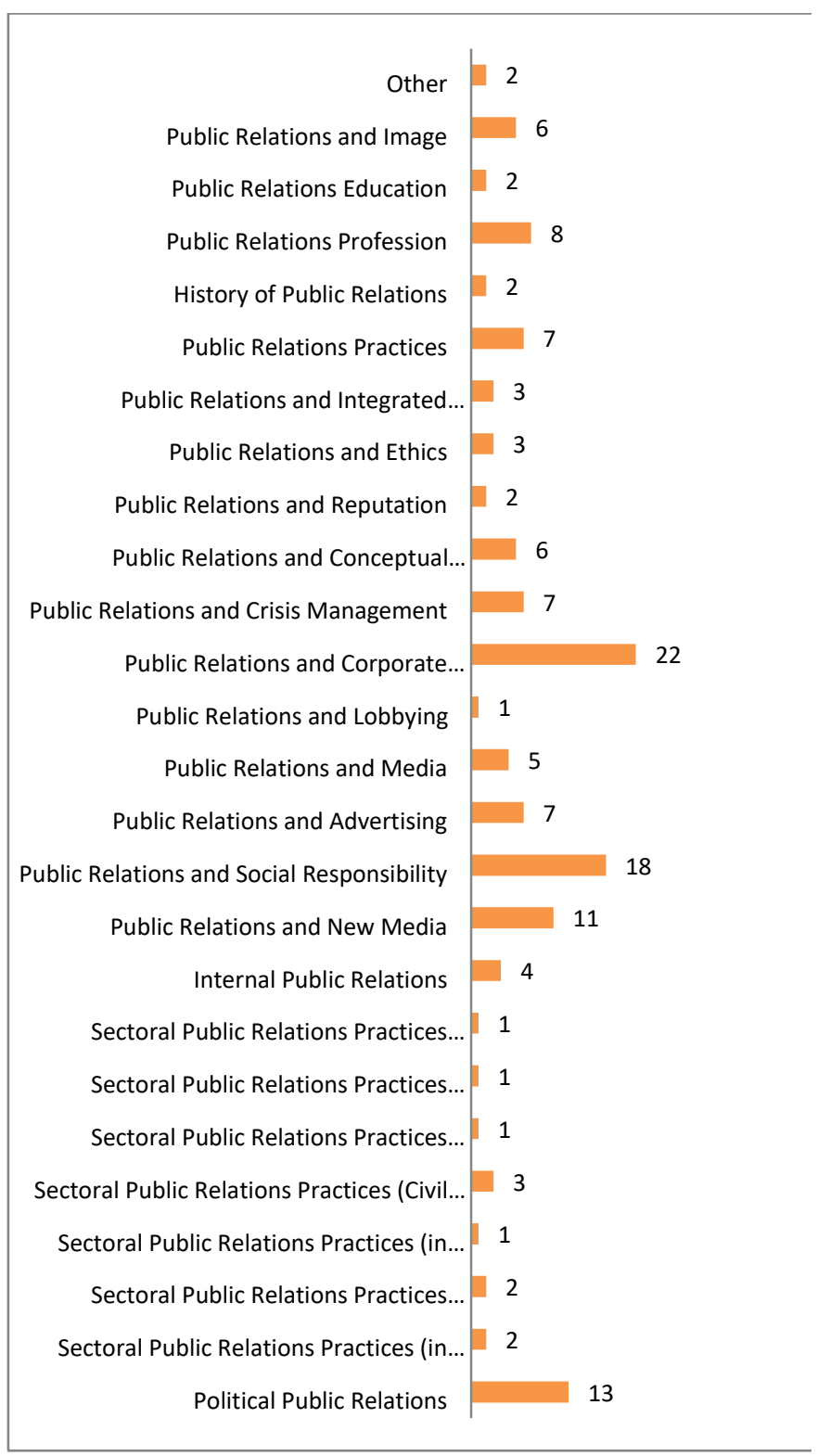

When we look at data on Figure 7 , which answers the question: "What is the distribution of scientific publications made by female authors in the field of public relations according to their subjects?"; we see that first place is held by the subject of Public Relations and Corporate Communication with 22 articles, second place by Social Responsibility with 18 articles, followed by Political Public Relations with 13 articles and Public Relations and Media with 11 articles. When we look at the subjects with the least number of articles; we see Public Relations and Lobbying, Public Relations Practices in the Education Sector, Public Relations Practices in the Retail Sector, Public Relations Practices in the Private Sector and Public Relations Practices in the Tourism Sector with 1 article each.

\section{RESULT AND SUGGESTIONS}

A total of 2,586 articles were reached within the scope of Gazi Communication Theory and Research Journal, Istanbul Communication Faculty Journal, Marmara Communication Journal and Selcuk Communication Journal in order to reveal the profile of academic articles published by female authors in the field of public relations in Turkey. It has been determined that 275 articles are on public relations, and 140 of these articles (with single author) are written by female authors from the first issues of the academic journals. We see that among 328 authors of the articles observed within the scope of research (single authored); $59 \%$ (193) are female and $41 \%$ (135) are male. In this context, it is seen that the number of female authors of articles published in the field of public relations is higher than that of male authors.

As a result of bibliometric analysis of articles published by female authors in the field of public relations, which dates back to 1960s in Turkey, and became a department within communication faculties in 1990s; it has been concluded that the number of qualitative/theoretical articles is more than quantitative ones. We see that among 140 articles authors of the articles observed within the scope of research (single authored); 119 are 
Qualitative/ Theoretical and 21 of them are Quantitative articles. When we look at the research with the gender variable, it is observed that 214 of the 275 articles published only in the field of public relations have $78 \%$ of the qualitative / theoretical research items and 61 of them have the quantitative research item with a slice of $22 \%$. It turns out that the qualitative / theoretical research type is higher. Thus, it can be said that the difficulty of collecting research data in the field of public relations in Turkey, the fact that the archive tradition is not very developed. In addition, this situation may have been caused by attempts to establish consensus on concepts due to the fact that in the 1990s, when the communication faculties and the public relations departments were established, there were also considerable resource problems in the field of public relations, major shortcomings in the literature, and lack of clarity on the basic concepts and coverage of public relations. From this finding, it is possible to make an interpretation that the number of articles containing the quantitative research method in the field of public relations, which has overcome the problems in Turkey at some point, should be increased today.

When we look at the distribution of academic publications by female authors in the field of public relations according to years; we see that there are 15 articles in 1994 (first), 13 articles in 2002 (second) and 11 articles in 2005 and 2011 (third). When the distribution charts of the single authored articles published in the field of public relations by the female authors are examined according to the distribution charts of five year periods, the highest number of publications (40) was made between 2002-2006; the second highest publication was published between 1992-1996 (31); and the number of publications between 2012-2016 is the lowest (15). The resulting data point to the fact that academic publications made in the field of public relations by female authors have declined over the last 10 years. In this context, underlining the necessity of studies is to increase the number of publications.

When we look at the distribution of academic publications by female authors in the field of public relations according to the institutions they represent; we see that Marmara University is in first place with 41 authors writing articles in the field of public relations, followed by 21 authors from Istanbul University and 15 authors from Gazi University. The resulting data indicate that this is in parallel with the names of faculties where public relations education started in Turkey. When we look at the distribution of academic publications by female authors in the field of public relations according to the provinces they represent; we see that Istanbul is in first place with 79 authors writing articles in the field of public relations, followed by 26 authors from Ankara and 9 authors from Izmir. The reason why Marmara University ranks first in terms of distribution of the authors is can be explained with the fact that the number of faculty members by 2012 is significantly higher and that the number of young academics who are increasing in numbers in the faculty of communication should make more publications due to the promotion criteria. The fact that Istanbul takes the first place in terms of number of publications can be explained by the fact that the most of communication faculties and the departments of public relations are in this city. There are 17 communication faculties in Istanbul, and 4 communication faculties in Ankara and İzmir.

When we look at the distribution of academic publications by female authors in the field of public relations according to their subject; we see that first place is held by the subject of Public Relations and Corporate Communication with 22 articles, second place by Social Responsibility with 18 articles, followed by Political Public Relations with 13 articles and Public Relations and Media with 11 articles. When we look at the subjects with the least number of articles; we see ublic Relations and 
Lobbying, Public Relations Practices in the Education Sector, Public Relations Practices in the Retail Sector, Public Relations Practices in the Private Sector and Public Relations Practices in the Tourism Sector with 1 article each. It can be concluded that the results of the studies that are more intense in the theoretical context are more intensive in their practical use. Concentration of female authors on subjects such as social responsibility and new media can be explained by the tendency to write on popular topics, where there is a relationship between the interests of academic articles and popular topics on the agenda. Thus, it can be said that the articles in academic journals in Turkey are in parallel with the interests of the sector. In addition, it is considered that the scope of public relations more handled in the context of businesses (Peltekoğlu 2016: 115). With this approach, public relations are trapped in business area. Public relations should be related with other disciplines theoretically and its power and impact area needed to be realized; so it does have the deserved place within sector. If a projection is to be made about the future of public relations in Turkey according to the data obtained data; we can say that the public relations sector, in which women are especially concentrated as general practitioners, should be strengthened as an academic discipline. For this reason, it is necessary for the public relations in Turkey to move away from shallow discussions and to be associated with different disciplines and academic studies should be done in this direction. In case of academic promotions and academic studies, it is necessary to focus on the quality, than quantity. The importance of archiving in the sector and the sharing of information with the academy are considered as important factors which will contribute to the progress of public relations discipline.

\section{REFERENCES}

Atabek, G., Ş., \& Atabek Ü. (2009). Halkla Illişkiler Literatürü: 1999-2008 Yılları Arasında Yayımlanmış Türkçe Makaleler Üzerine Bir Inceleme, Uluslar arası Halkla ilişkiler Sempozyumu, Uluslar arası Kıbrıs Üniversitesi, 15-17 Nisan, 2009, Lefkoşa

Koehler, W. (2001). Information science as "Little Science": The implications of a bibliometric analysis of the Journal of the American Society for Information Science. Scientometrics, 51(1):117-132.

Okay, A.(2016) Health Communication Dergisinde yayınlanan Makalelere Genel Bir Bakış, 2011-2016 Yıllarındaki Makalelerin Ele Alınması, II. Sağlık Iletişimi Sempozyumu, Eskişehir Anadolu Üniversitesi, 3-4 Kasım 2016, Eskişehir

Peltekoğlu, F. B. (2016). Halkla ilişkiler Nedir?. İstanbul: Beta Basım Yayım Dağııım: (115)

Pritchard A (1969) Statistical Bibliography or Bibliometrics? Journal of Documentation, 25, 348-349.

Saniye, U., \& Akdağ, M. (2015).Dergilerde Yayınlanan Hakemli Makalelerin Bibliyometrik Profili:Selçuk iletişim Örneği, Selçuk iletişim Dergisi, 9(1),5-21

Tokgöz, O. (2003). Türkiye'de Illetişim Eğitimi: Elli Yıllık Bir Geçmişin Değerlendirilmesi. Kültür ve Illetişim, 6(2), 7-32.

Gazi iletişim Kuram ve Araştırma Dergisi, (2017) Arşiv: http://www.iletisimdergisi.gazi.edu.tr/arsiv.php [Çevrim içi 27.05.2017]

Istanbul iletişim Fakültesi Dergisi, (2017) Arşiv: http://www.journals.istanbul.edu.tr/iuifd/issue/archive [Çevrim içi 27.05.2017]

Marmara Iletişim Dergisi, (2017) Arşiv: http://e-dergimarmara.dergipark.gov.tr/maruid [Çevrim içi 27.05.2017]

Selçuk Iletişim Dergisi (2017) Arşiv: http://josc.selcuk.edu.tr/issue/archive [Çevrim içi 27.05.2017] 
